\title{
Albanian Society in the Optics of Traditional Values
}

\author{
Ina K. Zhupa \\ PhD Candidate \\ Professor at the Social Science Faculty, European University of Tirana
}

\section{Doi:10.5901/ajis.2013.v2n8p141}

\begin{abstract}
Every particular society besides affirmative universal values, or the affirmation of the above, retains its specification based on their own traditional values. Which ultimately also make it different from other societies, distinct from them, despite the growing trends of globalization. Social, political, economic changes in a society inevitably affect the change of values who believes and supports a society and their hierarchy when we have to select their useful in a situation. Along with these changes recast the way society action and that's the reason that we study the values of the society. However pillars of traditional values remains as a point of reference in the judgment to make a pretty diverse society and its collective behavior. We try to identify the traditional values of Albanian society and to achieve this we have chosen to take in analysis the Canon of Lek Dukagjin and the Canon of Laberia. Respectively in the north and the south part of the country, they have been domestic laws of behavior, cultural codes that have run all judgments and actions of people. A content analysis of them will help us build a profile of Albanian value patterns. And finally to see if we find this traditional values, behaviors usable in Albanian society today.
\end{abstract}

Keywords: cultural change, society behavior, traditional values, value patterns, the canon of lek dukagjini, the canon of laberia.

\section{Introduction}

People, most of the times, take decisions and perform different actions by being guided mostly by emotions and judgement of values rather than having a push from a good logical base, a pure rational base. Values are very important to be studied and if it is taken in consideration the status of the values as a spiritual metering, with which in co-ordinance, the individual, personally and as a part of different social groups, structures his own spiritual world, chooses the conceptual forms, his attitudes and the social interaction.

Their importance shows up if we have have in mind that there is an internal dynamic as for the spiritual world of special individuals, and also as for what is called "a collective consciousness" and that characterizes the spiritual "infrastructure" of the social groupings in different levels. All the societies, despite their differences, despite the economic, social and in the same time the value modeling, they have a pillar of the values that are traditional. Their mass changes from period to period and from society to society for the importance that they give to them as guiders of the everyday behavior. For this reason we have the necessity to understand more over the traditional Albanian values that we easily can find in the canon of habitude and then we can notice the modern days Albanian context how it approaches towards these values.

\section{Methodology}

The object of this study is exactly the clear crystallization of what defines something as a value and afterwards which can be considered as traditional for the Albanian society. This project is intended to be operated by following the quality method. This choice was made because we are interested to firstly understand what is considered a value and we can do this only by examining the literature that we have until modern days from sociologist, philosophers or political scientists that have worked in this case. Afterwards it is necessary to define what are called traditional Albanian values. We could understand this better by studying the codes of moral, in our case found inside the canons of habitude that have been running in Albania respectively in the north and in the south of the country. A contentment analysis of them would give us a clear panoramic view of the main pillars of the values that the Albanian society has followed. In the same manner, to take a look of the situation of the of the traditional values today in the Albanian society, as an examination not very in details and filled with the concrete perceptions of the people, we consider as possible to stay inside the frames of the quality methodology. So, we will analyses what the Albanian sociologists, psychologist and philosophers think about the 
reality of today in the traditional values of the Albanian society. We have chosen to stay more within the frames of theory rather than in practice in this project.

\section{Conceptual Definitions}

The values are ethical imperatives that guide the behavior of people. They express the meaning and purpose of a special group of people in a certain relationship (Korte/Schäfers, 1993;31). So, the value is a fantasy or the idea that a society has for something desired, aimed, which is accepted in a general way and is spiritually incorporated at the members of the society to be followed in their everyday life. Another definition, which in its core is much closer to the first one, it is found from the sociologist Giddens: "The values are ideas of the individuals or of groups of people for what is desired, good or bad." (Giddens, 2002;695). But these two last concepts with which are explained the values are two base categories of ethics, and that is why the problem of values is connected tightly with the theory of moral and with its philosophy.

The point that the view of the values should not be considered as something objective, as something external and independent from the subject, but as something identical with the values and with values subjective judgment, has spread especially in the 20th century by authors like Hartman and Scheler, two representatives of the phenomenological axiology in philosophy, Scheler supports the point of view that alongside the role of reason in the determination of the priority of the values from the individual, an important role is for emotions too. This happens because nevertheless how important might be the values of the group, the value of a person, of his life and the definition that this person does to himself is unrepeatable in the society and the person himself creates a judgment that in a way is his for the importance or unimportant of the special values despite from his group correspondence. But not in every occasion he is adapted with the hierarchy of the values of his own group, even though in the main principles he might agree. and here the main role that creates this changeability is played by emotions and feelings, which are experienced as completely differently in different individuals (different characters, different passions, etc.). Still according to Scheler, the values are divided into two parallel categories, in values of the person and values of things in themselves, in self values and foreign values (of the individual, representing group and others), in values of action and counteraction, of success and other purposes. Scheler tries to even build a hierarchy of values, because according to him "in every situation in which it is found or imagined by the individual, he must decide which is the main value that should guide his present or later action" (Scheler, 1981;49-50).

For more, he offers also some general criteria to distinguish the values with high status in this hierarchy from the lowest that worth not only for the individual but also for group of individuals, a hierarchy that will be identified in this study as well. For example, the values are more important, so they stay higher in the hierarchy, as often as appears the need to get oriented to them, when they are less separable with others (individuals or groups), as deep as it would be the pleasure of their fulfillment or achievement. This necessity of the definition of the importance of the values and their place in the hierarchy is connected also with the fact that according to Scheler in the cases of conflicts, should be analyzed the position of the value that is in the highest point in this conflict to understand why there was born a conflict and the tendency of its change on the base of the change of this value. in this way we have the possibility to be oriented good in the corresponding conflict and in its consequences.

\section{Values and their change}

We take it for granted that a mirror of the traditional Albanian values can be found by taking in examination the canons: the Canon of Lek Dukagjini and the Canon of Laberia. The canons are codes of behavior which have been applied in the old Albania as if they were certificated laws in the obligatory force of a powerful country. In their analysis of the content we notice that there are some common values that can be found written in both canons and applied in the both regions, in the south and north of the country. A base pillar that we find in both is family. A great family, with a closed hierarchic structure, where the central figure is the householder, the man of the house, the eldest. This is in both the canons, in the center of the society as a very important point of building the other structures of the society. This because in a way, family decided even for the marriage of the youngsters, for their jobs, for the relationships with others, friends or enemies. Giving up from the individualist autonomy, for Albanians was important the family cohesion. Each one in the family finds in the canon their role, with the rights and duties determined and everybody should respect and obey them.

Honor is a social value for every rich or poor man is said in the section 24 of the the Canon of Laberia, by highlighting this as an important value of a good society. The same importance for the honor we find in the Canon of Lek 
Dukagjini, where is determined that the personal honor is untouchable and who threats it cannot be forgiven and should be cleared with blood. (page 64, Canon of Lek Dukagjini). The same is for the trust in both canons. that can be considered in the list of the values in the meaning of it as a sign of respect to the oral deal, and its application with seriousness and obligatory force as it was in front of an attorney in the modern days. In the canon of Laberia in the section 29 paragraph 4, is said that the given trust is never overridden by anyone. In the Canon of Lek Dukagjini is said that the trust is a center of freedom and safety (page 82). This explains very well how important this is in the Albanian society to guaranty the freedom and safety, because if you are on the trust of somebody or you are given the trust for something, there is no chance for the person giving the trust to break this trust.

The hospitality and the concept that the canon built on the guest is one of the primary pillars of them and it is as well-known as a traditional Albanian value. The hospitality talks about a solidarity society, for a society which is dependent strongly in one another, very connected with the other and influenced by the other. Even from the canons is clear that the respect of the society towards an individual was highly dependent from the mass that the person respects this value, the hospitality. For example, in the Canon of Laberia, we find in the section 42 paragraph 6 that "for every guest is served the bread that the host eats". This last one shows a treatment of the guest as equal with the self, and even it is guaranteed a protection from the host when the guest is in his house. We find in the canons the reflection of a society that believes, a society that acknowledges the religions and respects them and also follows the religious rituals. The religious objects are sacred, they cannot be touched and they have their lands and their importance in the society. In the canon of Laberia, regarding to the freedom of faith, we find the ratification in the section 14 that "anybody and everybody are allowed and insured the right of a religion; against the lawbreakers the council of the unit has the right of punishment as strong as ban from the unit". In the canon of Lek Dukagjini is written for the church as an untouchable institution because the catholic religion was spread in the north of the country. The church had a special status and its laws and didn't obeyed to the laws of the canon. From the importance that we find expressed in the canons, I think that the religion has been a part of the traditional Albanian values even though religion was forbidden during the communism in Albania.

\section{And today? The traditional values?}

Related to the values and their influence in the actual society, must be said that is not contested firstly the influence of the traditional values in the Albanian society, especially of that part of the values that were supported by the communist regime for certain interests. Facing the new values of the western model, these values experienced a crisis but their independence from the economic system (independence that even Weber and Huntington pretend) was seen as their regeneration or as their change into new terms. An institutional transformation, despite of the weaknesses, were not accompanied with a fast transformation of the mentality or with a pre-preparation of the mentality of the Albanian transition. It is known that the dictators by forbidden the free word stop the evolution of the ideas.

This kind of authorization "... that every day more is losing in the family life, becomes really unbearable for the young generation, especially when it takes a political form. Has passed the time of the alliance between the family patriarch, this base of traditional values and the political totalitarianism. (Fuga, 2001;77). Nevertheless this authorization continues to appear in different shades in the mentalities of the people, especially of that generation that grew in the dictatorship. Even the personalities that appeared very modern with their ideas in the beginnings of democracy, proved that they couldn't and cannot escape from this tendency.

On the other hand, new values like the religious ones, have strongly revived: "The overthrow of the previous system of values, the state of unsafely and many other negative phenomena, brought the people to religion, as a factor that gives a safety and a salvation against this new reality, which didn't resembled the image that the people had created for the society of the open market" (Fuga, Kocani, Sinani, 1999;77). Naturally, here we cannot talk about a powerful influence of the religious values in the society but this is an indicator that should be taken in consideration in the future years and in later studies. Either to see how they influence from inside the hierarchy of values itself of the Albanian society, either for evidencing and studying how they influence in the other social-economic developments. But for this can serve the other studies more focused in this field.

In fact, an indicator of the new values of the western model is displayed in the attitude of the people towards the way of living, which still again is different from the conception of different generations. Nevertheless it is not written anywhere that the happiness of the citizens should be one of the orienting principles of democracy. It also includes the tendency for these kind of values like the general well-being, participation and influence of the citizens in the side of the community in decisions that are direct interest of the last, the stimulation of the feeling of responsibility of the citizens and 
also for the structures chosen to take decisions, the protection from the manipulation and control of certain sections, etc.

But now all these qualities of democracy were understood equally. Especially in the young generation was observed a tendency for a life in the west and possibly without working. Vasilika Shtëpani describes these phenomena: "In the conditions of knowing and confronting with an economically developed world, it is natural the birth of the desire and request for the achievement of higher living standards. Meanwhile many people understood that this becomes reality only with work, there are also certain categories, which didn't managed to adapt in this situation. The young age and the desire to have a luxury life by avoiding the job factor, influenced that many young people to search for the easiest way to get rich: drugs and traficiation" (Shtëpani, 2003: 22).

These "values" as the well-being, getting rich fast, etc. and often the roads that brought there were taken in a hurry from the western model had a not small influence in the hierarchy of values of the new democratic Albanian society. They put a big question mark in the value of working and stimulated phenomena so harmful for the economy and the society which have their footprints even today with the social problems they carried. Even this is a factor of the influence of the values or the anti-values in the society.

\section{Conclusion and reflections}

Starting from the definition of the values as the imagination or the idea that a society has for something desired, aimed which is generally accepted and incorporated spiritually in the members to be followed and honored in their everyday life, we analyzed which of those can be considered as characteristic traditional values of the Albanian society. By working on the canons we came to the conclusion that some of the traditional Albanian values are: strong family bond and they being too much influenced in their decisions and depended from the family structure which works in a hierarchic way by being led by male figures in an old age; personal honor as an inalienable value which is appreciated by the society and every individual is guided by it in the everyday behavior; trust as the rigorous respect by being loyal to the end for the given promise, the deal agreed even though this might be just oral as a conversation between two people; hospitality that explains a strong bond of Albanians with the community, with other people in general by giving them an important role and by sacrificing and supporting the guest (the other) in any time and by insuring protection. And of course, the religion, a society that depends strongly to religion and believes in the religious principles. Of course that the Albanian society in its economic, political and social changes will also affect the values, the mass of which in the traditional values stands strong where they are modeled and serves to be an object of a deep empiric study. But we can say that the traditional and hierarchic family has already experienced its first cracks and is transforming every day more the point of view for it. Values like trust, hospitality, don't seem to have much to do with the young generations, which seems to embrace more and more the western values that are related with a personal autonomy, with individualization, with the freedom to act without being dictated. Last, even the religion is worth being studied in what mass can be considered as one of the values in which the Albanian society can depend.

\section{References}

Popper, K. "La logique de la découverte scientifique" Paris, 1982

Bachelard, G. "Le Nouvel Esprit Scientifique" Paris, 1963

Fuga, A. "Shtigje drejt guvës së gjarprit" Tiranw, 2001

Fuga, A. "Majtas Jo Djathtas", Tiranw, 2003

Fuga, A.\&Kocani, A.\&Sinani, Gj. "Shqipëria në tranzicion dhe vlerat" Tiranw, 1999

Fuga, A.\&Dervishi, Z. "Ndërmjet fshatit dhe qytetërimit global" Tiranë, 2002

Feraj, H. "Kriza e përkryer e Shqipërisë" Tiranë, 2003

Shtëpani,V. "Droga dhe rinia shkollore" Tiranë, 2003

Scheler, M. "Der formalismus in der Ethik und die materiale Ëertethik", 12 Aufl. Halle, 1981

Gehlen, A. "Der Mensch. Seine natur und seine Stellung in der Ëelt", 7Aufl. Frankfurt.Main\&Bonn, 1962

Giddens, A. "Sociologjia" Tiranw, 2002

Habermas, J. "Struktuëandel der ffentlichkeit" Berlin, 1962

Habermas, Jürgen: "Theorie des kommunikativen Handelns" Berlin, 1988

Inglehart, R., Wayne E. Baker, Modernization, Cultural Change, and the Persistence of Traditional Values American Sociological Review, 2000,Vol.65 (February);

Inglehart, R. Globalization and Postmodern Values, Ëashington Quarterly 23.1 (2000);

Kelle \& Lüdemann: "Theoriereiche Brückenannahmen?" në Kölner Zeitschrift für Soziologie und Sozialpsychologie, 31996.

Korte, Schäfers. Einführung in Hauptbegriffe der Soziologie,Hrsg. 2 Auflage UTB 1993; 
Lamentoviç, V. "Paqëndrueshmëria politike në Europën Lindore dhe Qëndrore". Në përmbledhjen e Verner Vajdenfeld "Demokracia dhe ekonomia e tregut në Europën Lindore", Tiranë, 1999;

Lecomte, J. Raisons de vivre. Raisons d'agir, Sciences Humaines, No 79, 1998;

Kanuni i Labwrisw, i kodifikuar nga Prof. Dr Ismet Elezi, Tiranw, 2006

Kanuni i Lek Dukagjinit, i mbledhur nga At Shtjefwn Gjecovi, Tiranw, 1999 